J. Lake Sci.(湖泊科学), 2008, 20(5): 613-622

http://www.jlakes.org. E-mail: jlakes@niglas.ac.cn

(C)2008 by Journal of Lake Sciences

\title{
青藏高原沱沱河地区新生代湖相白云岩特征及其环境意义*
}

\author{
李军鹏 ${ }^{1,2}$, 伊海生 ${ }^{1}$, 林金辉 ${ }^{1}$, 周肯肯 ${ }^{1}$, 黄华谷 ${ }^{1}$ \\ (1: 成都理工大学, 成都 610059) \\ (2: 中国石油新疆油田分公司，克拉玛依 834000)
}

摘 要: 青藏高原中部新生代湖泊发育普遍. 对该时期形成的湖相白云岩特征的研究对于了解当时及此后青藏高原的环境演 化进程具有重要意义. 笔者主要利用 XRD、SEM 及薄片观察方法对沱沱河地区两个剖面的白云石特征进行了研究, 分析了白 云石有序度、晶形及白云石中碳酸钻摩尔浓度三者之间的关系, 并根据白云石的矿物学和岩石学特征以及野外宏观岩层组合 特征对白云岩的成因作出了判断, 进而联系同一时期高原内部以及周边地区的构造运动导致的环境变化, 对剖面所代表地区 沉积时的环境变化作了解释.

关键词：青藏高原; 有序度; XRD; SEM; 白云石; 新生代

\section{Characteristics of Cenozoic lacustrine dolomite in central Tibetan Plateau and its environmental implications}

\author{
LI Junpeng ${ }^{1,2}$, YI Haisheng ${ }^{1}$, LIN Jinhui ${ }^{1}$, ZHOU Kenken ${ }^{1}$ \& HUANG Huagu ${ }^{1}$ \\ (1: Chengdu University of Technology, Chengdu 610059, P.R.China) \\ (2: Xinjiang Oilfield Company, Karamay 834000, P.R.China)
}

Abstract: Lakes developed widely during Cenozoic era in central Tibetan Plateau. Researches on those lacustrine dolomite formed in that period is highly significaive to analyze the evolutionary process of Tibetan Plateau environment from then on. XRD, SEM and thin section analytical approaches were applied to analyze the relationship among Degree Order, crystal shape and the $\mathrm{CaCO}_{3} \mathrm{molal}$ fraction of the dolomite samples took from Tuotuohe area. Based on the mineralogy and petrology features, investigation depends on the field work on the outcrops, and the origin mode of dolomite are diagnosed. Furthermore, the environmental changes recorded within the sedimentary sections are interpreted in connection with some tectonic movements which led environmental changes internal or external the Plateau.

Keywords: Tibetan Plateau; degree of order; XRD; XEM; dolomite; Cenozoic era

古近纪-新近纪交替前后是中国气候格局出现重大变革的时期，研究表明青藏高原的隆升是引发我国 新生代气侯格局变化的关键环节, 并且对全球气侯变化产生了重要影响 ${ }^{[1-2]}$. 然而在青藏高原隆升历史对中 国气侯环境演变影响的研究中，目前主要依据深海记录和黄土堆积序列，而缺乏高原内部资料的验证.

本文的目的是针对研究程度高且地层时代比较明确的沱沱河地区新生代地层序列, 系统采集沉积记 录完整的剖面中的碳酸盐样品，通过分析和研究工作，了解渐新世雅西错群和中新世五道梁群沉积环境 的变化历程，进而为了解青藏高原隆升过程中关键时代的环境变迁提供线索.

前人在对白云岩成因机制的研究中，主要的研究方法和思路是根据同生、成岩以及后生作用过程的 分析，对碳酸盐的沉积环境进行综合考虑并进一步推断白云岩的成因. 由于目前在常温常压下实验室内 仍然未能合成出真正化学计量的白云石, 所以关于其成因机制的研究仍然是碳酸盐岩研究方面的一个重

* 国家自然科学基金项目(40572077)资助. 2007-09-17 收稿; 2008-06-26 收修改稿. 李军鹏, 男, 1979 年生, 硕士研究生; E-mail: junpenglee@163.com. 
大课题. 也正因为如此, 吸引了大量的研究者 ${ }^{[3]}$ 对不同时代和地区的白云岩进行研究, 以期在白云岩 的成因理论上获得进一步的认识. 20 世纪 60 年代以来, 有众多研究者对澳大利亚的库龙泻湖中正在生 成的原生白云石进行了研究; 此外, 中国青海小柴旦盐湖湖滩岩中也发现了原生沉淀的白云石 ${ }^{[4]}$. 但 在自然界中白云岩的产出方式并不主要为原生沉淀，而更为常见的是通过准同生期或者成岩后期的交 代作用实现, 这已经为众多的研究所证实; 并且前人 ${ }^{[3-5]}$ 研究表明成岩环境对白云岩的形成影响巨大. 现今较为常见的几种白云岩的成因机制中, 都对其成岩环境有重要的分析和要求. 这些研究从另一个 方面而言积累了大量利用碳酸盐岩进行环境分析的方法和实例. 基于此, 通过对论文涉及的研究区内 新生代湖相白云岩的研究, 并结合其它研究成果和资料, 可以为了解当时及此后的青藏高原环境演化 进程提供重要信息.

\section{1 区域地质概况}

研究区地处青藏高原腹地沱沱河地区. 主要出露地层有始新世风火山群, 渐新世雅西错群和中新世 五道梁群. 渐新世雅西错群岩性主要为紫红色、黄灰色砂岩, 黄灰色泥岩夹灰绿色泥灰岩、泥晶灰岩及 含石膏粘土岩和石膏层. 中新世五道梁群岩性主要以浅灰绿、灰黄色薄-中厚层状泥灰岩、泥晶灰岩夹浅 灰色含灰质粘土岩、石膏岩及岩屑砂岩等组成, 岩石组合以泥灰岩、粘土岩及石膏层为主.

雅西措群生物以狍粉、轮藻和介形虫等微体古生物为主, 提供年代意义的主要为 Eucupris lenghuensis, 为渐新世标准分子或重要分子. 五道梁群所含生物以微体古生物孢粉和介形类为主, 孢粉组合显示的时 代为第三纪, 主要属种有裸子植物 Cedripites, Pinuspollenites 等, 被子植物花粉有 Tricolpites, Quercoidites 等. 介形类有中新世标准分子或重要分子 Eucypris goibeigouensis Sun, Candoniella marcida, Mandelstam 等 $^{[6]}$. 本次研究野外实测剖面为沱沱河地区第三系雅西措群(YP 剖面)和五道粱群(WP 剖面), 剖面位置如 图 1 所示. 雅西错群(YP)剖面位于通天河西岸, 距沱沱河约 $40 \mathrm{~km}$ 处, 地理坐标为 $92^{\circ} 18^{\prime} 55^{\prime \prime} \mathrm{E}, 34^{\circ} 18^{\prime} 52^{\prime \prime} \mathrm{N}$. 剖面顶底界清楚, 底部与下伏风火山群以底砾岩为界, 顶部与上覆五道梁群平行不整合接触, 以黄褐色 粘土层与之区隔. 剖面共分 55 层, 总计厚度 $1741.75 \mathrm{~m}$. 剖面白云岩及灰岩产出层位计有 8 层, 厚度约为 $186.42 \mathrm{~m}$. 五道梁群(WP)剖面位于沱沱河东南 $20 \mathrm{~km}$ ，地理坐标: $92^{\circ} 38^{\prime} 40^{\prime \prime} \mathrm{E}, 34^{\circ} 07^{\prime} 56^{\prime \prime} \mathrm{N}$. 剖面底部以黄褐

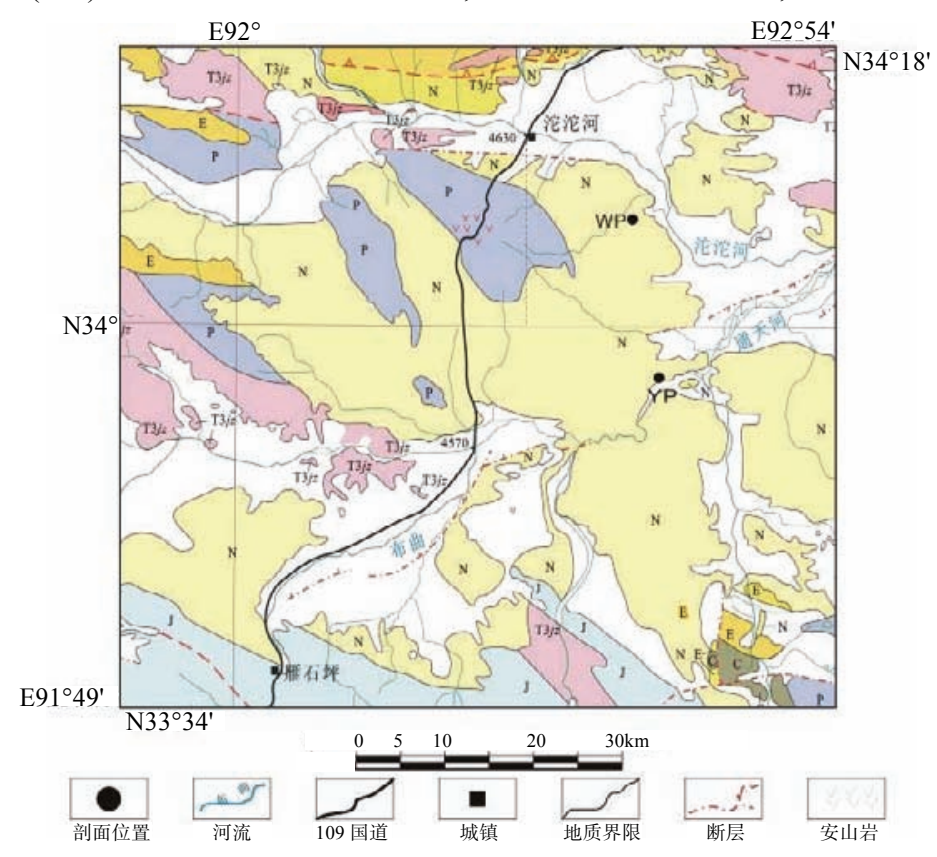

图 1 剖面位置分布示意图

Fig.1 Location of the section 
色粘土层与下伏雅西措群分界, 顶部由于河流切割出露不全. 共分 32 层, 总计厚度 $526.78 \mathrm{~m}$, 白云岩及灰 岩产出层位计有 8 层, 厚度约 $86.76 \mathrm{~m}$. 两个剖面研究取样的白云岩的产出层位如表 1 所示.

表 1 研究区白云岩的分布层位及产状

Tab.1 The distribution and attitude of Dolomite in the region of interest

\begin{tabular}{llccc}
\hline 剖面 & 野外产状 & 层号 & 样品 & 厚度 $(\mathrm{m})$ \\
\hline 五道梁群 & 灰黑色泥晶灰岩 & 22 & Wp22B1 & 19.83 \\
WP 剖面 & 灰色泥灰岩夹不等厚石膏层 & 19 & Wp19B1 & 19.88 \\
& 灰白色泥晶白云岩 & 16 & Wp16b1 & 6.04 \\
& 灰绿色泥岩与黄灰色泥灰岩互层 & 14 & Wp14b1 & 23.76 \\
& 灰绿色泥晶白云岩间夹黄灰色泥晶白云质灰岩 & 8 & Wp08b1 & 6.45 \\
& 黄灰色薄层板状泥晶白云岩 & 2 & Wp2b & 6.75 \\
& 灰绿色薄片状泥晶灰岩 & 1 & Wp0114B3 & 4.05 \\
雅西错群 & 薄层泥晶灰岩夹薄层石亳 & 54 & Yp54b1 & 7.24 \\
YP 剖面 & 黄褐色泥晶灰岩 & 37 & Yp37b1 & 24.22 \\
& 紫红色-灰绿色泥晶灰岩与紫灰色砂岩互层 & 35 & Yp35S1 & 49.97 \\
& 紫红色泥晶灰岩与黄灰色砂岩互层共 8 个旋回 & 32 & Yp32S1 & 20.84 \\
& 黄灰色膏质泥晶白云岩夹石膏层 & 22 & Yp22S2 & 48.88 \\
& 灰色泥晶灰岩 & 12 & Yp12S1 & 13.92 \\
& 叠层石白云岩与灰色泥岩不等厚互层 & 10 & Yp10B1 & 13.15 \\
& 黑色薄层状泥晶灰岩 & 8 & Yp08S1 & 8.00 \\
\hline
\end{tabular}

\section{2 实验测试方法}

本次野外工作所取样品多为泥晶白云岩或泥晶灰岩. 针对这种情况, 主要采用薄片分析、扫描电镜 和 X 射线衍射研究方法对两个剖面的白云石进行了分析研究.

薄片分析方法主要利用光学显微镜对岩石的主要矿物成分、组构等特征进行分析. 在对所采样品中 的碳酸盐岩取样磨片时先用稀盐酸法进行了初步的成分鉴定，以大致区分出白云岩、灰岩及其在岩样中 样中的大约含量; 在磨片时用茜素红进行了染色处理.

根据薄片观察分析的结果并考虑岩性和岩石组构特征, 精心挑选了部分样品用以进行超微组构分析 测试. 为了达到理想的图像分辨率的要求, 在扫描电镜观察之前对所有样品进行了镀银预处理, 测试过 程中多角度观察和照片. $X$ 射线衍射一般取样品 $5 \mathrm{~g}$ 左右, 用玛瑙研钵将样品研磨至粒度约 $2 \mu \mathrm{m}$ 左右以供 分析，再用压片法将粉末粘至玻片上而后送人仪器获得衍射图谱.

扫描电镜使用仪器为 HITACHI S-530 型扫描电子显微镜; X 射线衍射仪为日本理学电机公司生产的 DMX-IIIC 型衍射仪. 实验使用 FeKa、电压为 $35 \mathrm{kV}$ 、电流为 $20 \mathrm{~mA}$, 温度控制在 $25^{\circ} \mathrm{C}$. 由成都理工大学 分析测试中心完成此两项实验测试工作.

\section{3 白云岩矿物学特征}

1913 年英国 Bragg 推导出利用 $\mathrm{X}$ 射线进行晶体结构分析的基本公式(Bragg 方程 $\left.{ }^{[7-8]}\right): 2 d \sin \theta=n \lambda$. 式 中 $d$ 为晶面间距、 $\theta$ 为 Bragg 角. 该公式在白云石的研究方面具有重要的意义和作用. Goldsmith 与 Graff 用 $\mathrm{X}$ 射线衍射方法研究了白云石晶体结构的有序无序现象, 提出用 $I_{(015)} / I_{(110)}$ 的比值来表征白云石晶体结 构的有序无序现象, 称之为有序度 ${ }^{[9]}$. 现在, $X$ 射线衍射分析方法已经成为碳酸盐矿物鉴定与研究最重要 的手段之一，在方解石和白云石的鉴定分析上具有重要的意义. 可以实现碳酸盐矿物的成分鉴定, 方解 石中 $\mathrm{MgCO}_{3}$ 摩尔分数的确定, 白云石中 $\mathrm{CaCO}_{3}$ 摩尔分数及有序度测定以及碳酸盐矿物的定量分析. 进而 


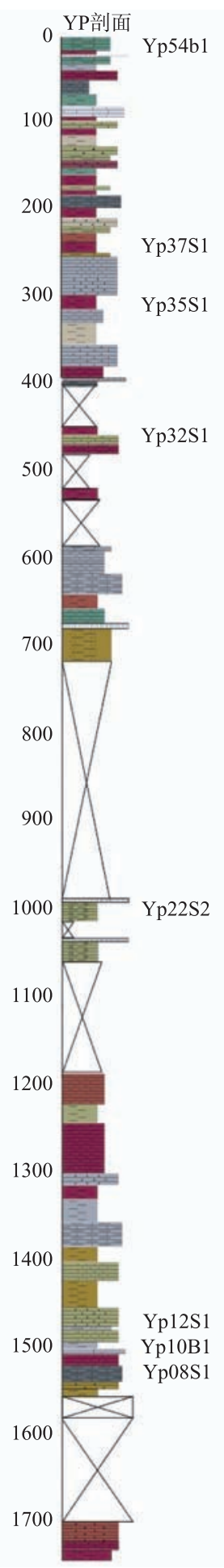

图 2 实测剖面岩性柱状图

Fig.2 Lithological column of the measured sections
可以从晶体的结构出发, 考虑晶体结构、白云石 有序度及形成环境这三者之间的关系，对白云岩 作出了一些微观方面的定义和说明.

在利用 X射线衍射图谱进行矿物成分判断时, 根据其原理, 准确的判别标志就是矿物晶体的特 征图谱. 每种晶体结构与其 X 射线衍射图谱之间 存在一一对应关系，任何一种晶态物质都有自己 独特的 $X$ 射线衍射图谱, 而且不会因为与其它物 质混合在一起而发生变化, 这就是 $\mathrm{X}$ 射线衍射法 进行物相分析的依据 ${ }^{[8,10]}$.

在 $X$ 射线衍射图谱上，白云石与镁方解石的 本质区别是具有超结构反射. 通常可以利用(镁) 方解石的最强衍射峰的面网间距值 $d_{(104)}$ 来求得 $\mathrm{MgCO}_{3}$ 摩尔分数; 而在计算白云石中 $\mathrm{CaCO}_{3}$ 的 摩尔分数时, 通常利用 Lumsden 和 Chimahsuky ${ }^{[7]}$ 推导出的公式: $N_{\mathrm{CaCO}_{3}}=m d_{(104)}-911.99$ 式中, $m=333.33, d_{(104)}$ 为分析样品中白云石的最强 衍射峰的面网间距值, 以 $\mathrm{nm}$ 计; 则白云石的摩

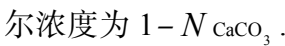

在方解石和白云石含量相差不大的混合样品 中, 这两种矿物最强衍射线绝对强度比值近于 $1: 1$, 则可以直接在衍射曲线上, 根据两种矿物最

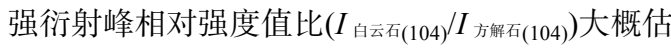
计两种矿物的相对含量.

白云石有序度变化源于其晶格中 $\mathrm{Ca}^{2+}$ 与 $\mathrm{Mg}^{2+}$ 的互相换位, 晶格中 $\mathrm{Ca}^{2+}$ 层的 $\mathrm{Mg}^{2+}$ 被 $\mathrm{Ca}^{2+}$ 取代或 是 $\mathrm{Mg}^{2+}$ 层的 $\mathrm{Ca}^{2+}$ 被 $\mathrm{Mg}^{2+}$ 取代都将提高白云石的 有序度. 当有序度值为 1 时，白云石晶体结构完 全有序 $\left(\mathrm{Mg}^{2+}\right.$ 层和 $\mathrm{Ca}^{2+}$ 层相间排列，中间夹一层 $\mathrm{CO}_{3}{ }^{2-}$ 阴离子层); 如果值小于 1 , 表示白云石的晶 体结构具有不同程度的无序 $\left(\mathrm{Mg}^{2+}\right.$ 和 $\mathrm{Ca}^{2+}$ 混杂在 同一层内); 有序度为 0 时, 两种阳离子在各层中 的排列分布情况完全无序.

白云石的有序度与白云石中方解石的摩尔浓 度具有正相关关系. Wp01-12B2 样品有序度取最 大值 0.77 , 其方解石的摩尔浓度也为最大值 57.33. Yp22S2 样品有序度为最低值 0.39 , 其方解 石的摩尔浓度亦为最小值 52.6(表 2).

影响白云石晶体结构的主要因素为矿物的有 序度和结晶所用的时间. WP 剖面较 YP 剖面结构 疏松, 孔缝较发育, 沿孔缝生长的白云石由于有 较好的生长空间, 晶形较好, 从而提高了整体的 有序度. 这说明随着白云石晶体有序度的提高, 白云石的晶形在向理想的晶形演变. 
表 2 XRD-粉末衍射实验数据和结果

Tab.2 XRD experimental data and result

\begin{tabular}{ccccc}
\hline 样品号 & 方解石摩尔分数 & 有序度 & 方解石 $(\%)$ & 白云石 $(\%)$ \\
\hline Wp22B1 & & & 100 & \\
Wp19b1 & & 0.58 & 100 & 91 \\
Wp16b1 & 55.67 & & 96 & 4 \\
Wp01-14B3 & & 0.60 & 14 & 86 \\
Wp14b1 & 56.67 & 0.77 & 70 & 30 \\
Wp01-12B2 & 57.33 & 0.63 & 40 & 60 \\
Wp08b1 & 56.00 & 0.52 & 27 & 73 \\
Wp-2b & 55.67 & & 100 & \\
Yp54b1 & & & 100 & \\
Yp37b1 & & & 100 & \\
Yp35S1 & & 0.39 & 100 & 90 \\
Yp32S1 & & 0.52 & 10 & 96 \\
Yp22S2 & 52.60 & & 100 & \\
Yp10B1 & 54.43 & & & 4 \\
Yp08S1 & & & & \\
\hline
\end{tabular}

\section{4 岩石学特征}

\section{1 白云岩显微分析}

WP 剖面白云岩均为泥晶白云岩. 岩石结构致密; 有机质含量较高; 镜下见有隐粒结构藻纹层理; 底 部层位岩样薄片观察见有粉砂级内碎屑, 其外观大小均一, 磨圆好, 显示经历了长距离或长时间的的搬 运改造作用. 该剖面白云石的形成可能与兰绿藻类生物生命活动相关. 为了与剖面中的白云石进行对比, 选择了该剖面两个层位的灰岩进行了鉴定. 灰岩多产出于剖面的上部层位，见有机质. 陆源石英颗粒有 次生加大边, 磨圆较好. 灰岩结构疏松, 含有大量介形虫和轮藻生物化石. 轮藻化石外形清晰完整, 内部 被方解石充填但不完全. 由白云岩以及灰岩的显微结构来看, WP 剖面主要为水体能量较低的近岸浅湖环 境, 水深不大, 较为稳定.

YP 剖面白云岩镜下特征同上部 WP 剖面, 然结构相比而言稍疏松, 见有砂级内碎屑. 白云岩中孔缝 多被陆源石英矿物颗粒或细晶－微晶方解石充填, 但不完全. 微一细晶方解石多以充填方式生长于孔隙 边缘. YP 剖面灰岩层位占优势. 灰岩中化石主要以介形虫和轮藻类生物化石为主, 有机质呈团状分布, 溶孔、溶洞和裂缝常见. YP 剖面代表了近岸浅湖到滨湖环境. 个别薄片中发现的少量陆源碎屑石英矿物 可能为沉积时河流流水注人盆地时所携带, 但由于水量有限且间歇性或者持续时间较为短暂故不多见, 这也与主体的蒸发环境相一致.

\section{2 白云石超微组构特征}

通过对两个剖面的白云石的 SEM 照片进行调查观察，按照白云岩中白云石晶体之间的组合形式可 归纳出以下几种超微组构类型:

(1) 凝胶状组构, 主要由细小的凝胶状白云石颗粒组成, 相互粘结, 晶体个体边界不清晰. 组合体粒 径多大于 $1 \mu \mathrm{m}$, 单体粒径多小于 $1 \mu \mathrm{m}$, 单体晶形差, 为它形.

(2) 镶嵌状组构, 指粒径大于 $1 \mu \mathrm{m}$ 的自形一半自形晶体点缀于粒径小于 $1 \mu \mathrm{m}$ 的半自形一它形晶体之 间. 这种结构多见于生物化石本身或是孔缝、溶洞处.

(3) 蜂窝状组构, 晶形多为半自形一它形, 整体结构疏松多孔缝. 晶体单体粒径小于 $1 \mu \mathrm{m}$, 超微孔隙 发育. 
按照粒径的不同可以将所研究的白云石分为两类: 第一类白云石为它形晶, 粒径小于 $1 \mu \mathrm{m}$. 第二类 白云石为自形晶，粒径多大于 $1 \mu \mathrm{m}$. 中间存在过渡类型. YP 剖面白云岩镜下可见明显的致密层与疏松层 的的分界. 白云石晶体晶形常为半自形一它形，具有较好晶形的白云石晶体多生长于疏松层与致密层的 分界处. WP 剖面的白云岩溶孔、缝常见，白云石的晶形较 YP 剖面为好, 多为半自形一它形. 较好晶形者 白云石晶体一般见于溶蚀孔洞、孔缝中. 两个剖面中, 随着白云石晶形向自形完整方向变化; 与之适应, 有序度也同步提高.

两个剖面白云石晶体粒径的变化规律具有一致性. 一般而言呈它形晶者粒径小于 $1 \mu \mathrm{m}$, 呈半自形或 是自形晶者粒径大于 $1 \mu \mathrm{m}$. 根据镜下观察的结果，晶形较好者多见生长于孔缝、溶蚀孔洞中. 可见生长空 间对于白云石晶形的调整意义重大. 而这种调整对于研究区而言可能是在成岩晚期阶段通过长时间的晶 体内部两种阳离子的互换而使得白云石的晶形向理想的方向发展; 少数具有完全自形晶形的白云石的形 成可能是后期淡水参与作用的结果.

由 Yp10B1 样品的 7006 照片可以看出, 呈纤维状的石膏晶体生长于白云石晶体的晶间孔缝中, 晶体 晶形完整，说明二者的形成应为同一时间，该层位白云石的形成与强烈蒸发的成岩环境关系密切. 而 WP 剖面白云岩整体结构致密, 孔隙多为晶间孔. 白云石的形成多与藻类的生命活动有关, 在 SEM 照片中多 见呈蜂窝状组构的白云石发育.

总体而言白云石晶体的粒径呈明显的二分趋势，以 $1 \mu \mathrm{m}$ 为界. 粒径的不同又对应不同的晶形. 粒径 小于 $1 \mu \mathrm{m}$ 者晶形一般较差, 为半自形一它形; 粒径大于 $1 \mu \mathrm{m}$ 者晶形则以它形一半自形为主. 具有较好晶 形的白云石晶体所处空间一般为孔缝周边或内部. 说明晶体晶形完整与否与有无生长空间关系密切. 不 同粒径白云石的形成时间不同，粒径大者比较小者为晚.

根据镜下鉴定特征，辅以 XRD 及 SEM 分析结果，笔者认为研究区白云岩的形成在时间上经历了两 期成岩作用阶段：第一期为它形晶形成阶段，晶体粒径 $<1 \mu \mathrm{m}$, 为岩石主体组成成分; 第二期为自形晶形 成阶段, 晶体粒径 $>1 \mu \mathrm{m}$, 为后期调整作用的结果. 主要是先期形成的白云石受后期成岩流体的改造再结 晶而形成的产物. 整体而言, 白云石的形成与成岩作用密切相关.

\section{5 白云岩成因分析}

对于白云石有序度与白云石中碳酸钙摩尔浓度变化的关系而言, 前人研究结果表明有序度愈高对应 碳酸钙摩尔分数的降低 ${ }^{[4,9,11-12]}$ (向 $\mathrm{Ca}_{50} \mathrm{Mg}_{50}$ 的理想构成靠拢). 事实上, 白云石的的成分范围可以在 $\mathrm{Ca}_{56} \mathrm{Mg}_{44}$ (化学计量白云石)到 $\mathrm{Ca}_{50} \mathrm{Mg}_{50}$ (原白云石)之间变动，该研究区样品显示有序度的提高对应的是白 云石中碳酸钙摩尔分数的提高. 由此可见，仅以有序度的变化与碳酸钙摩尔浓度变化之间的关系来确立 白云石的成因(原生的或是次生的)并不是充分条件. 作者认为, 该研究区这种变化关系可能与晶体内部 两种阳离子的互换相关，在这一过程中并没有或很少有外来阳离子的加人, $\mathrm{Mg}^{2+}$ 层的弱势 $\mathrm{Ca}^{2+}$ 与 $\mathrm{Ca}^{2+}$ 层 弱势 $\mathrm{Mg}^{2+}$ 的对换, 晶体向稳定状态转换, 表现为有序度提高但摩尔分数并不会发生大的变化. 研究区沉 积环境可以为这种离子的互换提供必要的条件. 野外宏观尺度上雅西错群与五道梁群碳酸盐类一个突出 的的产出特征为低能环境的泥晶灰岩/白云岩与石膏互层, 可见白云岩或是灰岩沉积时所处的环境为蒸 发量超过补给量的一个蒸发环境. 这种沉积环境较正常的开放式湖泊体系而言, 能够为白云石矿物向更 稳定的化学结构转变创造条件; 其二, 石膏结晶产出为有利于白云石沉淀的 $\mathrm{Mg}^{2+} / \mathrm{Ca}^{2+}$ 比值保持稳定甚至 在某一时间段内呈上升趋势提供了保证. 这两者共同为研究区白云石有序度变化与碳酸钙摩尔浓度变化 之间的这种关系提供了合理的解释.

根据以上研究，白云岩的成因主要与环境和菌藻类生命活动两个因素有关. 沱沱河地区白云岩沉积 时, 随着湖泊水体的不断蒸发, 在剖面上依次出现碳酸盐、硫酸盐等岩石类型. 澳大利亚的库隆泻湖是现 在存在的可以发现原生白云石的地区之一，其环境为海岸泻湖，但不与蒸发岩共生 ${ }^{[3,10]}$. 由此可见，虽然 同为蒸发环境，沱沱河地区白云岩的成因与其具有明显的不同(有膏盐互层)，可能不但有蒸发环境因素， 也有菌藻类生命活动的原因. 我国青海小柴旦盐湖湖滩岩中发现的原生白云石就被认为是菌藻成因 ${ }^{[12]}$. 前人通过对白云石的研究发现，藻类的生命活动能够为白云石的沉淀创造条件，原生白云石的沉淀多与 
生物特别是藻类的生命活动有关 ${ }^{[10,13]}$. 藻类生命活动及其生物体本身为白云石的沉淀提供了适宜的弱碱 性沉积环境和较高 $\mathrm{Mg}^{2+} / \mathrm{Ca}^{2+}$ 比值. 在薄片观察中可见有的薄片中生物种类较少, 藻丝体大量繁殖, 水动 力条件较弱, 沉积环境稳定, 从而有利于白云石的形成; 有的虽然也可观察见有藻丝体, 但是夹杂以陆 源的石英、长石等矿物, 生物种类也较为复杂, 水动力条件较强, 沉积环境不稳定, 藻丝体难以存活, 不 能提供一个长期稳定的适宜白云石生长的环境, 故生成方解石.

由于白云石显微组构中一般呈泥一微晶状, 缺乏交代早期碳酸盐沉积物的特征, 与石膏互层并有藻 纹层, 野外多呈薄层产出 (层厚 $<0.5 \mathrm{~cm}$ ), 并结合以上所述的白云石矿物学和岩石学特征, 以及沉积环境的 判别, 可以认为沱沱河地区新生代雅西错群(YP 剖面)和五道梁群(WP 剖面)白云岩的主体部分为准同生 或早期成岩作用的产物.

\section{6 结论及讨论}

潘保田 ${ }^{[14]}$ 等人通过研究青藏高原隆起的基本过程指出中新世早期青藏高原地区普遍经历了一次很 强的构造运动, 西瓦利克群沉积就是在这一阶段接受来自北方的碎屑物质沉积而成, 标志了喜马拉雅山 脉的隆起. 青海东北部贵德盆地渐新世至中新世早期的西宁群的紫红、橘红色砂砾岩、砂岩和粉砂质泥 岩也可以从近于相反的方向说明这一时期高原北部的构造挤压隆升活动 ${ }^{[15]}$.

安芷生 ${ }^{[16]}$ 等认为在中新世 $25-14 \mathrm{Ma}$ 之间中新世以来发生在青藏高原及周边与构造变形有关的隆升 事件主要为西昆仑南北向缩短, 天山及祁连山发生早期隆升, 青藏高原东北缘隆升, 临夏盆地周边山体 隆升, 南部部分地区变形分解形成伸展运动; 与此隆升时间序列对应的沉积特征主要有高原北部陆相环 境代替海相环境，柴达木盆地开始形成，高原北部前陆盆地沉积物源区发生变化，阿尔金山前形成巨厚 的砾岩沉积, 南部也有大量的砾岩堆积.

沱沦河地区新生代雅西错群与五道梁群在一定程度上反映了以上提及的同一时期高原内部沉积环境 的变化进程. 由于所处位置为青藏高原腹地，造成其沉积物与周边的盆地有所不同，主要沉积了一套河 流及湖泊相碎屑岩和碳酸盐岩. 而通过盆地沉积的碳酸盐岩的矿物学, 岩石学的研究则可以在一定程度 上展现中新世高原隆升对内外部环境所造成的影响. 渐新世、始新世雅西措群以碎屑岩为主的沉积组合 向中新世五道粱群碳酸盐湖泊相沉积组合为主的转变可能与中新世早期的构造运动有关, 但是需要更加 精准的年代数据方面的支持. 由于沱沦河盆地中新世五道梁群出露较差, 顶底面较为完整连续的剖面至 今未见有发现, 而且由于本次研究样品所在的剖面未见有良好的可以提供年代意义的生物化石, 所以对 于雅西错群与五道梁群之间沉积机制转变的具体时间目前还无法给以准确的定位.

但是通过对研究区雅西措剖面和五道粱剖面白云石的矿物学及岩石学特征进行研究, 结合岩层野外 宏观产出所反映的沉积环境的变化, 可以得出以下结论:

(1) 研究区白云石的矿物学、岩石学特征与沉积期间的干旱环境具有密切的因果关系. 沱沱河地区新 生代准同生白云岩的成因主要由化学和生物两个因素所控制. 化学因素主要体现为剖面中石膏层重复出 现, 典型代表为雅西错群与蒸发岩共生的白云岩; 生物因素主要是指藻类的生命活动为白云石的沉淀创 造了条件. 在五道梁群部分层位白云岩或者灰岩中可以发现叠层构造或是藻纹层, 为菌藻类生物生命活 动遗留下来的印迹.

(2) 在渐新世、始新世雅西措群向中新世五道粱群的转变过程中, 雅西错群可以代表当时沱沱河地区 沉积环境整体以湿润为主，间有几次短暂的干旱气候事件; 而沉积五道梁群期间内则干旱的气侯环境占 优势. 由此可见, 青藏高原在渐新世、始新世到中新世这一地质时期内，早期以湿润和干旱事件的交替出 现为其特征, 晚期则以干旱的沉积环境为主，这种被岩石记录所反映出来的环境变迁主要是中新世早期 青藏高原一次重要隆升事件的结果.

致谢: 野外工作期间夏国清、武向峰和姜否等同学大力协助; 孙霞、马雪等同学在室内实验时给予了较 多帮助，在此一并表示感谢! 


\section{7 参考文献}

[1] 施雅风, 汤森苍, 马玉贞. 青藏高原二期隆升与亚洲季风孕育关系探讨. 中国科学(D 辑), 1998, 28(3): 263-271.

[2] 刘东生, 郑绵平, 郭正堂. 亚洲季风系统的起源和发展及其与两极冰盖和区域构造运动的时代耦合性. 第四纪研究, 1998, 3: $194-204$

[3] David TW. The role of sulphate-reducing bacteria and cyanobacteria in dolomite formation in distal ephemeral lakes of the Coorong region, South Australia. Sedimentary Geology, 1999, 126: 147-157.

[4] 夏文杰, 李秀华. 青海小柴旦盐湖湖滩岩中原生白云石的发现及其意义. 沉积学报, 1986, 4(2): 19-25.

[5] 黄思静, Hairuo QING, 胡作维等. 四川盆地东北部三叠系飞仙关组碳酸盐岩成岩作用和白云岩成因的研究现状和存在问 题. 地球科学, 2007, 22(5): 495-504.

[6] 青海省地质矿产局. 区域地质调查报告 1:20万沱沱河幅章岗日松幅. 西宁：青海人民出版社, 1989: 53-59.

[7] 刘岫峰. 沉积岩实验室研究方法. 北京: 地质出版社, 1991: 8.

[8] 叶大年. X 射线粉末法及其在岩石学中的应用. 北京: 科学出版社, 1984: 4.

[9] 邓 敏, 钱光人, 唐明述. 白云石晶体的有序度与去白云石化反应. 南京化工大学学报, 2001, 23(1): 1-5.

[10] 曾允孚, 夏文杰. 沉积岩石学. 北京: 地质出版社, 1986: 6 .

[11] 曾＼cjkstart理，万茂霞，彭＼cjkstart英. 白云石有序度及其在石油地质中的应用. 天然气勘探与开发, 2004, 27(4): 64-68.

[12] 李秀华. 白云石的微化反映与有序度. 矿物岩石, 1995, 15(2): 31-34.

[13] 刘宝郡, 张锦泉. 沉积岩成岩作用. 北京: 科学出版社, 1992: 8.

[14] 潘保田, 李吉均, 朱俊杰等. 青藏高原: 全球气候变化的驱动机与放大器( II. 青藏高原隆起的基本过程). 兰州大学学报, 1995, 31(4): 160-167.

[15] 宋春晖, 方小敏, 李吉均等. 青藏高原东北部贵德盆地上新世沉积环境分析及其意义. 第四纪研究, 2003, 23(1): 92-102.

[16] 安芷生, 张培震, 王二七等. 中新世以来我国季风一干旱环境演化与青藏高原的生长. 第四纪研究, 2006, 26(5): 678-693.

[17] 孙＼cjkstart枢. 中国沉积学的今后发展: 若干思考和建议. 地学前缘, 2005, 12(2): 3-10.

[18] 刘再华, Dreybrodt W, 李华举. 灰岩和白云岩溶解速率控制机理的比较. 地球科学, 2006, 31(3): 411-416.

[19] 张学丰, 胡文瑄, 张军涛. 白云岩成因相关问题及主要成因模式. 地质科技情报, 2006, 25(5): 32-40. 
图版及说明

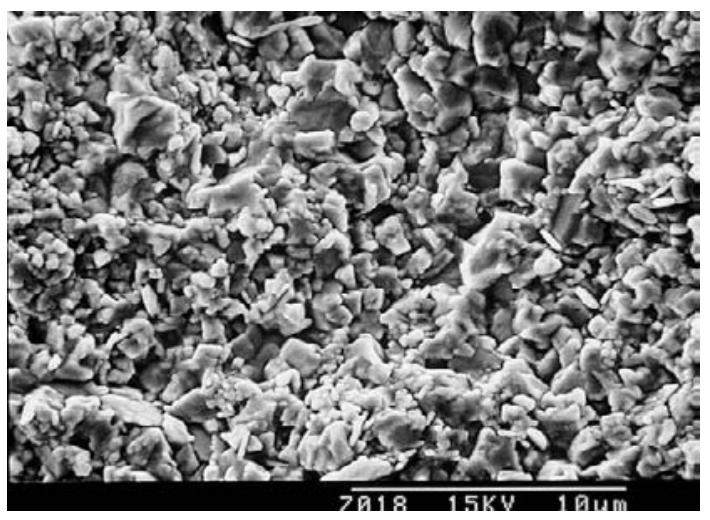

7018

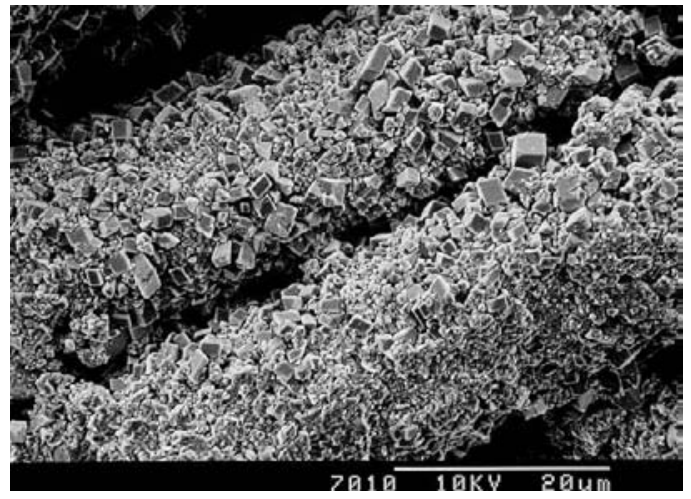

7010

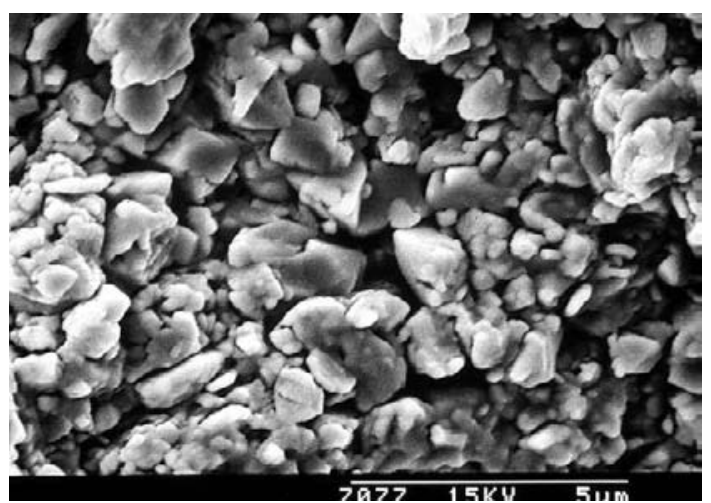

7077

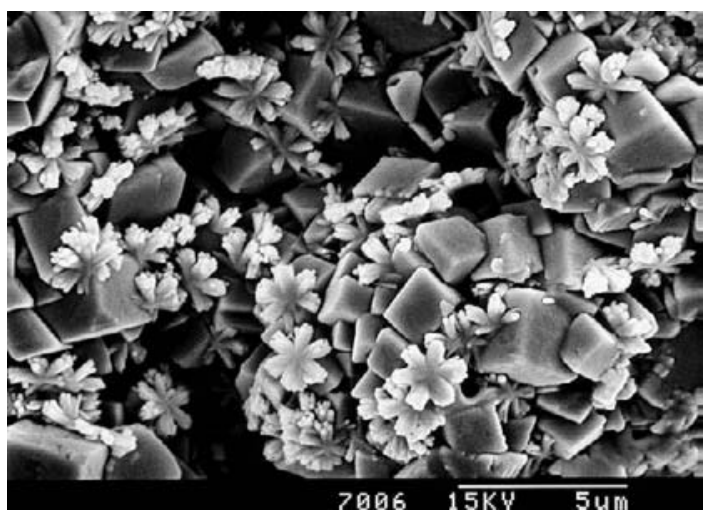

7006

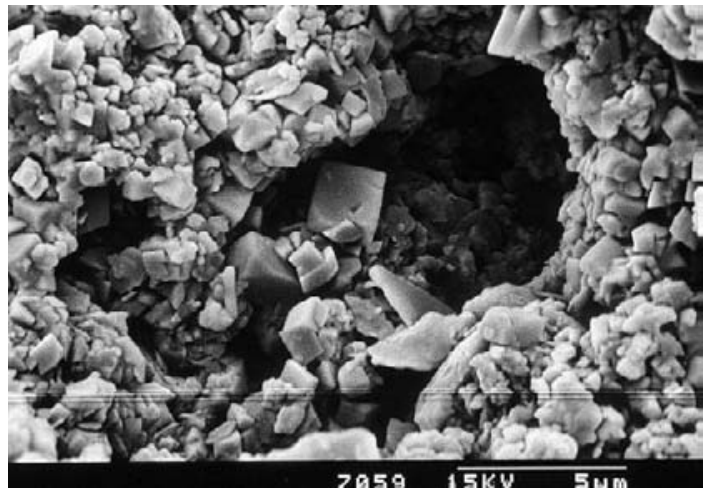

7059

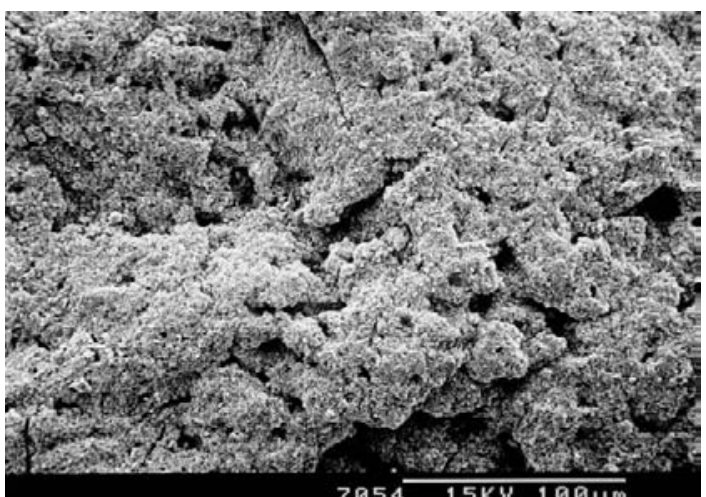

7054

7018: 致密层白云石呈它形、粒径 $<1 \mu \mathrm{m}$ 、呈凝胶状则多大于 $1 \mu \mathrm{m}$.

7006: 白云石晶间孔中的纤维状石膏晶体, 生长在白云石晶间孔缝中. 粒径小于 $2 \mu \mathrm{m}$, 其周围白云石晶形自形完整.

7010: 棒状生物体超微照片. 由自形白云石晶体 $(>1 \mu \mathrm{m})$ 和它形的白云石晶体 $(<1 \mu \mathrm{m})$ 组成. 自形白云石晶体呈镶嵌状散布 于占优势的它形白云石晶体中.

7059: 孔缝周边白云石晶形较好, 成自形晶, 与相邻白云石粒径有明显反差.

7077: 白云石晶体粒径均小于 $1 \mu \mathrm{m}$, 晶形成半自形一它形, 以半自形者居多.

7054: 整体结构松散, 疏松多孔缝, 晶体成半自形一它形. 粒径小于 $1 \mu \mathrm{m}$. 


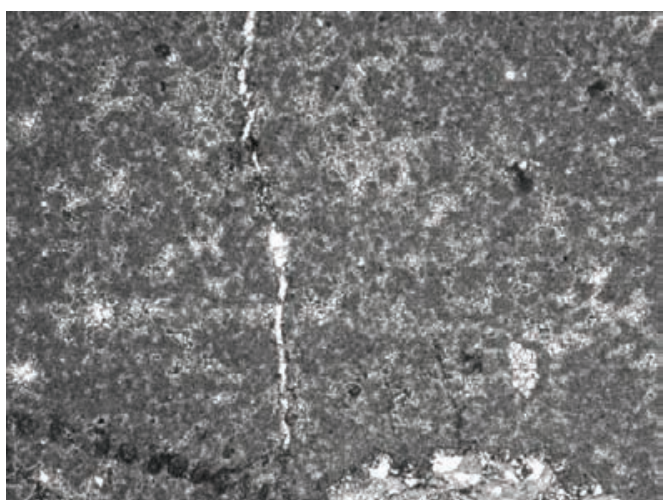

170

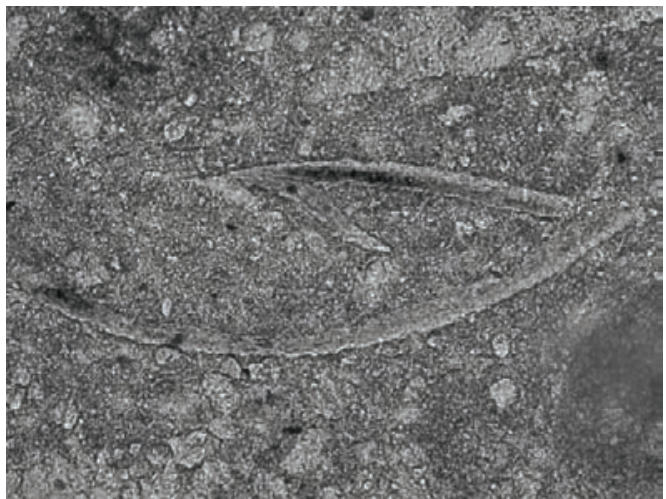

105

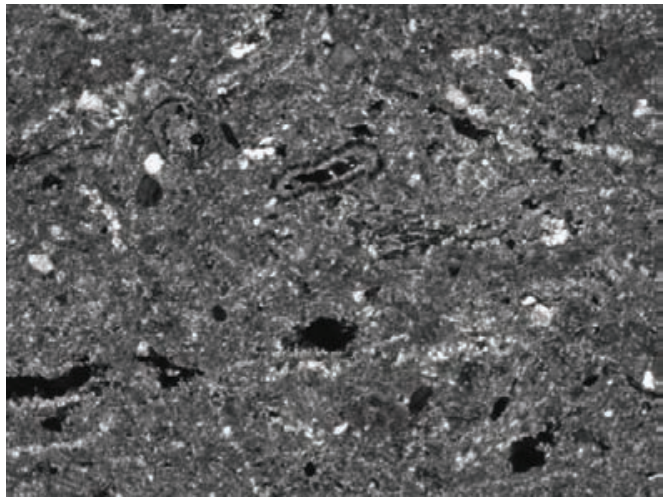

175

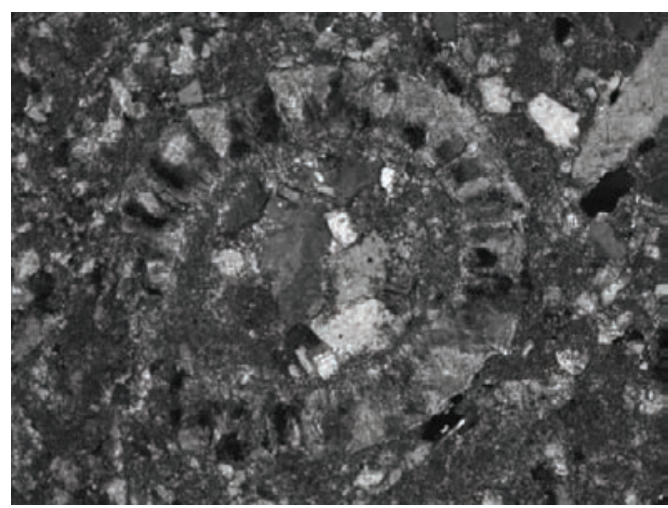

206

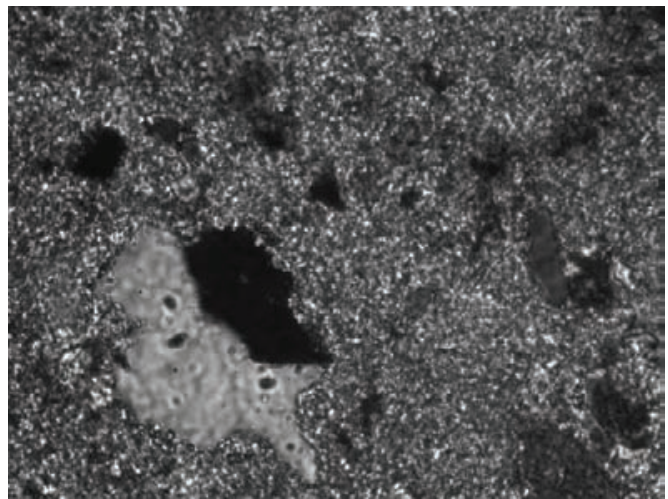

101

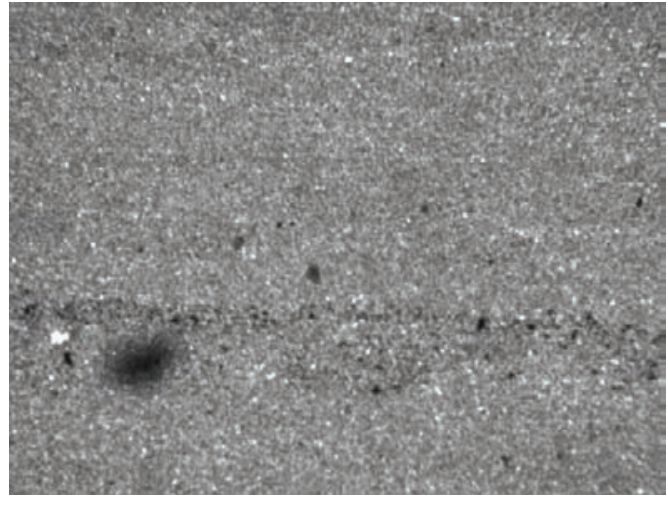

116

170: 砂屑泥晶灰岩. 单偏光, $\times 10$, 藻纹层隐粒结构, 样品代号: Yp22S2.

206: 微晶一细晶生物碎屑灰岩. 正交偏光, $\times 10$, 轮藻化石, 外形完整, 内腔被细晶方解石充填, 样品代号: Yp 35S1.

105: 微晶一细晶生物碎屑灰岩. 单偏光, $\times 20$, 介形虫化石, 样品代号: Yp35S1.

101: 微晶一细晶生物碎屑灰岩. 正交偏光, $\times 40$, 陆源石英矿物, 具次生加大现象, 样品代号: Yp 35S1.

175: 含砂生物碎屑灰岩. 正交偏光, $\times 4$, 结构疏松, 孔缝发育, 可见介形虫及轮藻类生物化石, 样品代号: Wp22B1.

116: 灰白色泥晶白云岩. 正交偏光, $\times 4$, 结构致密, 有机质成点染条带状分布, 样品代号: Wp16b1. 